\title{
Los Salmos como oraciones de los pobres
}

\author{
James McPolin, \\ Centro de Reflexión Teológica, \\ San Salvador, EI Salvador.
}

"Los Salmos normalmente han sido redescubiertos en tiempos de opresión"1. Este vigoroso juicio de un escriturista contemporáneo afirma que la voz universal de los pobres y desposeídos, la cual podemos escuchar muy claramente hoy en día, tiene un fuerte eco en los Salmos. La voz de los pobres de hoy nos permile redescubrir, al igual que a ellos, los Salmos y el Dios de los pobres al que ellos se dirigen. El tema de la pobreza en la Biblia está siendo reexaminado en nuestros días como respuesta al clamor de los pobres y a la luz de nuestras situaciones de pobreza nacional e internacional y de la siempe creciente brecha entre ricos y pobres, resultado de las estructuras trastomadas de nuestra sociedad. A muchos niveles, eruditos, escritores de temas espirituales y poetas ${ }^{2}$ están tratando de cerrar la brecha entre los textos de la Escritura, originalmente compuestos para situaciones de hace mucho tiempo y su significado, en un mundo nuevo compuesto por diversas culturas, condiciones y problemas. Algunos escritores muestran cómo una comprensión renovada y más realista de los "pobres" en los Salmos puede favorecer una reflexión propiamente teológica en apoyo del pobre y del marginado de hoy ${ }^{3}$. Nuestra propia sensibilidad ante situaciones humanas de privación e injusticia y el hecho de tener un mayor conocimiento de los derechos humanos, particularmente los del pobre, y de las diferentes formas de opresión que se realizan en la sociedad, pueden ayudamos a desarrollar nuevos puntos de vista sobre los Salmos cuando los leemos a la luz de las luchas de los pobres y de la justicia social.

Los Salmos describen a Dios como el salvador de los pobres, como su esperanza, su forlaleza y su libertador, ya sean aquellos oraciones de un individuo o de una comunidad. En el culto, donde los Salmos eran rezados con frecuencia, el pobre parece recobrar sus derechos. Al menos ahí, el orden de Dios todavía se mantiene: 
Comunica, oh Seffor, al rey tu juicio,...

para que defienda la causa de los pobres del pueblo,...

y dé liberación a los necesilados.

$(\mathrm{Sal} 72,1.4)^{4}$

El Seflor es una plaza fuerte para el oprimido, una plaza fuerte en las situaciones de angustia...

El no puede olvidar el clamor de los anligidos...

El que está en necesidad nunca será olvidado...

$Y$ la esperanza del pobre nunca quedará frustrada.

(Sal 9, 10.13.19)

(El Dios de Israel) hace justicia a los oprimidos, proporciona su pan a los hambrientos, libra de sus cadenas a los presos.

Abre los ojos de los ciegos, endereza a los que andan encorvados, da el Señor protección al forastero y mantiene a los huérfanos y viudas.

(Sal 146, 7-9)

En el culto se puede sentir que Dios está presente sosteniendo al pobre. El templo mismo parece ser el trono de la justicia para el oprimido. Probablemente, el templo fue un santuario, un lugar donde se podia tener una experiencia tangible del cuidado y compasión de Dios. El pobre, quien puede sentirse estigmatizado y humillado, se siente rescatado por Dios de estos sentimientos de separación, inferioridad y autodesprecio. Los Salmos no tendrán, por tanto, nada que ver con la visión de que los pobres son no sólo desafortunados, sino también inferiores. Ellos lienen un Dios salvador. Ellos tienen a Dios a su lado. En su lucha contra los enemigos, siempre pueden volverse hacia Dios. Siempre tendrán en Dios a alguien que los escuche.

Por otra parte, los Salmos no parecen ocupar un lugar muy preferente en la lista de los escritos de la Biblia más comúnmente escogidos hoy por los escritores cristianos para sus reflexiones acerca de la pobreza y de la justicia. Muchos cristianos rezan estos Salmos sobre los pobres, individualmente o en grupos, sin relacionarlos con la situación social de los marginados y de los totalmente despojados. Generalmente, la solicitud preferencial de los cristianos para con los pobres no parece estar en conexión con el Salterio, la oración oficial de la Iglesia. Aun con las ayudas proporcionadas por los estudios modemos y por traducciones muy competentes, el Salterio, y particularmente los Salmos que se refieren al pobre, sirven predominantemente como formas de espirituralidad personales e individuales. Los Salmos no han sido integrados a una espiritualidad o a una teologia social, sino que más bien se centran en quienes material y socialmente son pobres y desposeídos en la sociedad y en su relación 
hacia Dios y hacia nosotros mismos, que en nuestra propia experiencia personal de ser "pobres", ya sea espiriual o materialmente.

Ciertas dificultades y malentendidos podrian explicar en parte este hecho. Por ejemplo, algunas veces podramos tener la impresión de que los Salmos primariamente conciernen a los "espiritualmente pobres" (quienes confían en Dios y lo reconocen como la fuente de toda vida) y de que casi nada tienen que ver con aquella gente material y socialmente oprimida por la injusticia También se debe decir que muchas cilas y el lenguaje sobre los pobres pueden parecer a veces muy vagos y sin relación con las situaciones de la vida de los pobres de hoy. Sin embargo, es posible salir al paso de algunas de estas dificultades y mostrar que algunos de estos Salmos acerca del "pobre" en Israel, pueden ser leídos como oraciones del pobre, para el pobre, y cantados como canciones para nuestro mundo moderno. "La situación contemporánea del mundo de hoy", dice Carrol Stuhlmüller en su reciente comentario sobre los Salmos, "es un ingrediente esencial para la correcta y completa apreciación de la palabra de Dios en la Biblia. Nosotros enfatizamos la importancia de ubicar cada Salmo en nuestra Iglesia y en nuestro mundo contemporáneos, no sólo para una interpretación biblica exacta, sino también para indicar cómo la Biblia misma frecuentemente reinterpretó los Salmos"s.

\section{Palabras usadas en el Antiguo Testamento para designar al "pobre"}

El "pobre" (incluyendo el estado de hecho de ser "pobre" o "sufrido") aparece en treinta y tres salmos ${ }^{6}$ en diferentes grados de prominencia. Además, en otros salmos se hace mención de personas que, en realidad, son pobres material o socialmente, tales como "el hambriento, el desplazado, las viudas, los huérfanos", aunque las palabras hebreas comunes para referirse al pobre no sean utilizadas'.

Por lo general, en el Antiguo Testamento muchas palabras hebreas expresan la noción de pobreza, pero ninguna de ellas puede ser traducida exactamente por nuestro término "pobre". La palabra más común es 'änî en, su forma singulars. Literalmente describe a una persona agobiada, doblegada, que ocupa una posición muy baja. No tiene más remedio que admirar a los demás, está doblegada por la presión en una relación de dependecia, trabaja bajo una carga y no está en posesión de toda su fuerza y vigor. El 'änî es el humillado, el que no puede poner su cabeza en alto debido a la presión económica y social. Describe una posición de inferioridad y primariamente expresa una relación más que un eslado de angustia social. Cuando 'änî se usa en combinación con dal o 'ebyón. expresa más que todo una situación económica. En un uso más desarrollado. 'ánî implica un estado de humillación o angustia, por ende una persona en un estado de competencia muy reducido y de menor valoración. La palabra 'änōw. en arameo y en una forma secundaria hebrea (que siempre se encuentra en la 
forma plưral 'anöwîm en los Salmos'), está asociada muy cercanamente con 'äntí; son téminos intercambiables ${ }^{10}$. Ambos pueden expresar pobreza espirilual - material. Ambos están probablemente conectados con 'änäh, que significa "afligir", "oprimir" o "humillar a otra persona", y los sustantivos 'önit" y änût" que expresan "pobreza", "dolor moral" y "opresión". Básicamente, 'āni (o änōw) se refieren a aquellos que "están doblegados" o "que sufren". Este hecho explica por qué diccionarios y versiones de los Salmos dan una amplia variedad de traducciones: "que sufre", "pobre", "humilde", "oprimido", "humillado", "necesiLado", "débil", "bajo" o "sumiso". La debilidad implicada en la palabra hace posible traducirla como "sumiso", es decir, como alguien que no tiene ya voluntad para luchar.

Ebyôn ${ }^{13}$ describe a la persona que suplica (de 'äbāh, "querer" o "desear"). Originalmente, el 'ebyôn es el que pide limosna, el mendigo. Despues, la palabra llega a ser más usada por lo general para designar a la persona pobre. Una persona puede pedir en dos sentidos: a otras personas, como un mendigo, y a Dios. El 'ebyón es aquella persona a la que le falta algo y espera que olro se lo proporcione. En muchas versiones y diccionarios, el término es traducido por "necesitado", "pobre", "deseoso" y "oprimido".

$D a l^{4}$ es el "débil, frágil o lánguido" (de dälal que significa "estar colgado", "bambolearse", "estar abatido", "ser débil"). Esta palabra ha sido usada en relación a la debilidad física y aplicada después a la posición de las clases más bajas, de los campesinos como pobres, necesitados, insignificantes; describe, por tanto, a la gente desamparada o de baja posición. Frecuentemente, en el Antiguo Testamento significa el despojo material y social, sin ninguna otra connotación. Muchas versiones y diccionarios comúnmente lo traducen por "pobre". "necesitado", "débil", "desamparado", "bajo", "magro".

'Añi, dal, y 'ebyôn constituyen el lenguaje predominante para hablar del pobre en los Salmos. Ocasionalmente, están en relación con otras palabras tales como dak"s ("oprimido", de däkäh, lo mismo que "agobiar", "rebajar"), helkāh ${ }^{16}$ ("desventurado", "desafortunado") o "asuqûm" ("opresión"). Todas éstas no son descripciones neutrales; llevan una connotación emotiva. Originalmente, indicaban circunstancias que deben urgentemente cambiar. Ya casi al final del Antiguo Testamento aparece un têrmino neutral rî́" ("ser pobre", "estar necesitado"). Esta palabra describe neutralmente una situación económica y social. No debe sorprendernos, entonces, que nunca fuese usada por los profetas. Para ellos, la pobreza de su gente era siempre una situación finto de la opresión.

Este lenguaje para referirse a los pobres en los Salmos nos proparciona una pequetha visión sobre el significado radical de lo que fue ser pobres en la vida hebrea. Sin embargo, hay muchas y variadas tradiciones acerca del pobre en el Antiguo Testamento y, en consecuencia, este lenguaje debe ser escuchado atentamente no sólo desde su presentación literaria de los Salmos, sino también 
desde la siluación historica y social del pobre de Israel, que ellos reflejan. No podemos concluir meramente a partir de las palabras, si 'änî, 'ebyôn y dal expresan pobreza material o espiritual. De hecho, pueden indicar una de las dos o ambas, según los diferentes contextos y situaciones ${ }^{19}$.

\section{Los Salmos como historia de los pobres}

Los Salmos que se refieren al pobre abarcan un período largo de la historia de Israel. Contienen antiguas tradiciones de Israel acerca del pobre y reflejan diversas condiciones socioeconómicas desde los tiempos cananeos a los macabeos. A pesar de cambios tardíos y adiciones, muchos Salmos se remontan al perfodo pre-exilico, acercándose incluso a los tiempos de David y Salomón. Algunas veces van aún más lejos. El Salmo 68, por ejemplo, fue probablemente compuesto durante el reinado de Saúl (1200-1000 a. C.). Habla acerca del cuidado de Dios para con los pobres, huérfanos, desplazados, prisioneros y viudas (vv. 6.7.11). También el Salmo 76, una canción de vicloria que proclama a Dios como el salvador de todos los oprimidos del mundo (anōwîm, v. 10), parece reflejar la monarquía inicial ya sea bajo David o Salomón (1000-922 a. C.) o de Ezequias (715-687 a. C. ). Algunos defienden que es uno de los Salmos más antiguos y que pudo haber sido compuesto bajo David.

Una fecha tentativa con respecto a la composición inicial o final de estos Salmos acerca del pobre demuestra que estón enraizados en un enorme espacio de la historia de Israel y de su reflexión sobre la experiencia del pobre. La composición de estos Salmos debe ser relacionada con el tiempo del reinado de David, Salomón, incluso con el de Saúl ${ }^{20}$ o con el período inmediatamente anterior al exilio (587 a C.), especialmente con la epoca de los últimos profetas (por ejemplo, Jeremias) y de las invasiones asirias y babilonias ${ }^{21}$ y también con el tiempo durante ${ }^{2}$ y después del exilio ${ }^{2}$, durante y después de la reconstrucción del templo (520-515 a. C.), incluso durante el período en el que floreció la literatura sapiencial. Estos Salmos, pues, reflejarian una gran variedad de situaciones que los situaria directamente en el período del segundo templo (es decir, el templo de Zorobabel, reconstruído entre los años 520 y 515 a. C.), cuando los Salmos alcanzaron su forma actual. Aparte de su larga historia de composición, estos Salmos reflejan tradiciones acerca del pobre existentes mucho antes de que aquéllos fueran compuestos.

Tradiciones que encontramos en los libros del Exodo y del Deuteronomio y en los profetas aparecen a lo largo de estos Salmos. El cuidado de Dios por el marginado y pecador, por el "huérfano y oprimido" (Sal 10,18) rememora las antiguas tradiciones acerca del pobre, especial objeto de preocupación para Dios $^{24}$. Frecuentemente, los pobres son colocados bajo la protección de la alianza de amor (hesed) de Dios ${ }^{25}$. El cuidado especial de Dios para con los pobres es uno de los temas principales de los Salmos 9-10, que constituyen un 
único poema, probablemente escrito durante el periodo de la dominación asiria y babilonia Los pobres (incluyendo la condición de hecho de pobre, es decir, aflicción, pobreza) son mencionados frecuentemente. Hay muchas tensiones en esta oración: entre la nación de Israel y las naciones extranjeras, entre el sufrimiento de los pobres y el éxilo de los malvados, entre el Dios como siempre presente en el templo y aparentemente ausente en el tiempo de la angustia, entre la cálida compasión de Dios y la severa justicia en la causa del pobre. El Salmo debe ser relacionado con la alianza, que coloca a los pobres bajo la protocción especial de las leyes de Dios (Ex 20, 22 - 23, 33). Las necesidades del pobre, del afligido, del huérfano, del oprimido y del desamparado, están unidas a las grandes "hazañas" de Dios en la historia. El pobre puede sentirse seguro de la ayuda de Dios porque las tradiciones sobre el Dios que ayudó al oprimido en el pasado de Israel son la base de la esperanza del pobre $(9,7-11 ; 10,14-18)$. El Sefior siempre ha sido la ayuda de los "huérfanos" $(10,14.18)$ y el que les hace justicia Los "huérfanos" junto con las viudas y los forasteros representan, de acuerdo a una antigua tradición de la alianza, al totalmente oprimido, al necesitado y al desposeído (Ex 22, 22-24).

El cuidado del débil y desamparado no fue algo que se dio únicamente en Israel. Teóricamente, fue la obligación de los reyes del próximo oriente y la responsabilidad de al menos algunas de las divinidades. Pero en Israel existe una tradición muy clara y fuerte de que el Dios de Israel se caracteriza por la justicia y el cuidado de los pobres e indefensos (Salmos 9-10). El Salmo 82, que da un lugar prominente al pobre (llamado 'anî,, 'ebyôn, dal y räs), estí infilurado por la mitologia cananea sobre la asamblea de los "dioses" ("elōhûm). Refleja una tradición muy desarrollada sobre los dioses paganos y llega hasta la conclusión sobre quién es realmente divino, a partir de normas de compasión humana y de justicia social. Prácticamente,condena a los "dioses" paganos al mismo destino (la muerte) que a los jueces comuptos, egoístas, y a todas las autoridades que explotan al pobre e indefenso (vv. 5-6). Los dioses (elöhüm) cananeos fueron integrados a las tradiciones de Israel como una asamblea de seres sobrehumanos (los después llamados ángeles) y los seres humanos de alta posición fueron llamados a veces elöhûm (Ex 4, 16). Al usar esta tradición, el autor insiste en que la divinidad verdadera, ya sea en Dios o en sus representaciones, se decide por la preocupación por el débil y el destituido. La credencial para el verdadero Dios en la alianza mosaica es la de un Dios de perdón, de compasión y de abundante amor consitante (Ex 34, 6-7).

El Salmo integra un elemento cananeo a su teologia del pobre. También manifiesta el impacto de la predicación profética en su preocupación par el pobre y necesitado. La defensa del débil y destituido, descrita en este Salmo (vv. 2-5), era una tarea principal de los reyes y los jueces. El no llevar a cabo esta importante tarea fue condenado por los profetas clásicos. En su largo y complicado desarrollo, el Salmo muestra que la religión israelita no rechazaba 
inmediata y delinitivamente a lodos los otros dioses (especialmente a los que se preocupaban por los pobres). Reconoce también que la preocupación por el pobre y destituido no fue una preocupación exclusiva de Israel. La esencia del problema establecida en el Salmo es: ıpor qué los pobres e indefensos son continuamente despojados de la justicia? La respuesta es: por la mala administración por parle de los subordinados, los seres "divinos" que han sido dolados de la justicia para toda la humanidad, especialmente para el pobre y el necesitado ${ }^{26}$.

Dentro de la historia de la oración del pueblo, el "pobre" aparece en muchas formas de oración en el Salterio; por ejemplo, en los Salmos de alabanza, en las oraciones de súplica (o "lamento") individuales o comunitarias, en las acciones de gracias del individuo o de la comunidad, también en las formas más reflexivas de oración (salmos sapienciales) y en las oraciones que celebran al rey. No podernos estar seguros de hasta qué punto estas oraciones fueron compuestas directamente para la liturgia del templo. Es posible que para dicha liturgia hayan sido compueslos menos salmos de los que con frecuencia damos por supuesto. Se ha sugerido tambiên que la religiosidad laica jugó un papel importante en la formación de los Salmos.

El clamor del pobre debe ofrse dentro de su situación literaria e histórica. Por ejemplo, la palabra "pobre" puede tener un significado positivo o negativo según la situación. Puede tener un significado negativo si los pobres son los afligidos, despojados u oprimidos de la sociedad, subrayando en este caso el escándalo y la maldad de la pobreza. Por otra parte, el ser pobre puede significar estar en necesidad ante Dios, estar dispuesto a recibir a Dios, dirigirse a Dios en demanda de ayuda Ambos significados pueden combinarse para describir a quienes están despojados y abiertos a Dios.

Al leer la Escritura cuando habla acerca del pobre, también necesitamos preguntar. ¿quién dice, qué, dónde y a quién? Por ejemplo, algunas veces los autores de los Salmos se refieren a ellos mismos como pobres:

Seffor, piensa en mí, pobre y desdichado.

Tú que eres mi socorro y salvación, no te demores.

$(\mathrm{Sal}$ 40, 18)

Más frecuentemente, los pobres son nombrados como terceras personas:

Dios tendrá piedad del débil (dal) y del necesitado ('ebyôn), salvará la vida de los pobres ('ebyônîm).

$($ Sal 72,13$)$

Los autores también se pueden ubicar ellos mismos con los pobres cuando le piden ayuda a Dios. Ellos se ven participes en el cuidado y protección especial que Dios ofrece a los pobres y despojados: 


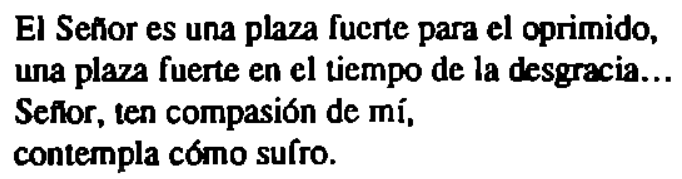

(Sal 9, 10. 14)

Algunas veces, el contexto literario e histórico nos permite conocer mejor quiénes son los pobres (toda la comunidad, o un gupo dentro de ella, o el autor solo) y en qué sentido son pobres (material, social o espiritualmente). Aun con todas estas ayudas, sin embargo, algunas veces es muy dificil determinar quiénes son los pobres en los Salmos.

\section{Las estructuras de la sociedad y los pobres}

Las diferentes tradiciones acerca del pobre en los Salmos están enraizadas en las diversas condiciones socioeconomicas de Israel desde los tiempos de los cananeos hasta la composición final del Salterio. El desarrollo socioeconómico de Israel está unido al penetrante tema del Dios de la alianza como defensor del pobre y necesitado, un tema que se encuentra en la literatura legal, en la profética, en la hímnica y en la sapiencial.

C. Boerma ${ }^{27}$ une el progreso de la pobreza a la transición que se dio en el antiguo Israel desde la vida nómada a la agrícola y urbana. En los primeros libros de la Biblia, durante la primera etapa de la historia de Israel (es decir, el período patriarcal, 2000-1300 a. C.), la riqueza y la pobreza no son un problema. En el Génesis, la palabra "pobre" no se menciona debido a que en el estilo de vida nómada tribal las posesiones nunca son un privilegio obtenido a expensas de otros. Las posesiones son riquezas de la tribu o de la alianza tribal en su conjunto. Si una persona es rica, todos los miembros de la tribu son ricos. En este contexto, las riquezas son vistas como una bendición de Dios, que es disfrutado por toda la tribu. La tierra es propiedad del Sefior a compartir por todos.

La pobreza no progres6 por su propia cuenta. Desde Egipto hasta el exilio (1200-587 a. C.), las estructuras de la sociedad cambiaron y crearon problemas. De ser seminómadas, los israelitas se convirtieron en agricultores pequeflos e independientes, cada uno posela una pequeña parcela. La base de la vida social ya no fue la tribu, sino la familia. Hubo diferencia entre quienes poselan tierra y los pobres. Las personas se volvieron rivales, en forma de grupos familiares, debido a los cambios de fortuna a consecuencia de las mejores o peores cosechas. A quienes se les habla dado una mala parcela al principio, pronto se volvieron pobres y tuvieron que venderse a sí mismos y a sus familias como esclavos. El desarrollo de una economía que incluía tratos de intercambio comercial, fue destruyendo la igualdad de las familias. Algunas de éstas se volvieron muy ricas y otras, lentamente, se volvieron pobres. La causa de la pobreza fue el hecho del cambio de la siluación social y económica. 
La brecha entre el rico y el pobre se hizo aún más grande con el desarrollo de la monarquía y el crecimiento de la fuerza armada, que estaba al servicio del rey. El rey se volvió muy poderoso, pues controlaba el ejército y la economia. Este monopolio real generó un grupo privilegiado de personas dentro de la ciudad, en contraste con una población pobre, establecida en el campo o en las zonas marginales de la ciudad. Debido a que estas personas tenían que proporcionar bienes y servicios a la conte y sus círculos, su existencia se volvió enormemente marginal. Se fueron empobreciendo cada vez más. En tiempo de crisis y de guerra, por el contrario, la clase privilegida más pudiente o "afortunada" iba consiguiendo engrandecer sus posesiones considerablemente. "Ay de aquel que une casa con casa, aquel que empalma un campo con otro campo hasta que ya no deja espacio para los demás y tiene que habitar solo en el centro de la tierra" (Is 5, 8). Estos ricos terratenientes, criticados por Isaías, se fueron apartando en gran manera del proletariado del campo que ellos mismos hablan creado.

Los cambios en las estructuras políticas y económicas transformaron el clima social. La atmósfera frugal de vida comunal dio paso a una gran pompa y a ceremonias asociadas con los palacios y las alianzas internacionales en que comercio, guerra y pactos jugaron un papel central. Surgí, entonces, una aristocracia próspera que contrastó con una población cada vez más marginal. El abismo entre el rico y el pobre se volvió más profundo. Después del exilio, la estructura básica permaneció igual, aunque se agravó más adelante, debido a las guerras y sus consecuencias.

Los cambios en las estructuras sociales, económicas y políticas influyeron en el conjunto de la construcción de las relaciones humanas. A los pobres, social y económicamente pobres, también se les hizo sentir inferiores. Se les despreció y oprimió; y todo esto debido a las estructuras de la sociedad. Al comienzo de la historia de Israel, la pobreza había sido un asunto de inferioridad económica. Despues, el rico empezo a tratar a los pobres como si éstos pertenecieran a un orden social inferior. Se llegó a considerar que tenfan menos derecho y menos juicio: "La sabiduría del pobre es despreciada y sus palabras se van sin que se les preste atención" (Qoh 9, 15). Además de ser pobres, fueron engañados, oprimidos, explotados. "Pobre" se convirtió en sinónimo de "oprimido" - oprimido por la gente violenta.

El Antiguo Testamento responde a esta pobreza, la cual tenia sus raices en las injusticias de la sociedad, con tres propuestas principales: la llamada a la justicia que quedó expresada en la ley, y particularmente en el cótigo de la alianza (Ex 20-23) en beneficio del pobre y del desposeído, y también en el mensaje de los profetas; la necesidad de la solidaridad; y un mensaje de experanza y de confianza para el pobre. Los Salmos elevan, en particular, un grito en favor de la justicia y la alianza y también dan experanza a los pobres. 
N. Gouwald ${ }^{23}$ presenta un análisis diferente del contexto social de Israel durante el perfodo 1250-1050 a. C., antes de la instauración de la monarquia El cuestiona la transición de la vida nómada a la vida agricola y urbana. Los israelitas no habran tenido su origen fuera de Canaán, entrando en la tierra como grupos nómadas resueltos a la conquista o como seminómadas o pastores nómadas que se infiltraron pacíficamente en la población establecida. El Israel primitivo habría sido una formación ecléctica de gente cananea marginal y deprimida, relacionada con una estructura social de ciudadestado. Al lado de los grupos sociales que rodeaban la ciudad-estado vivia un campesinado de pastores y de agricultores. Más afuera, en los márgenes, vivían los hebreos (apiru). Estos ofrectan sus servicios para el combate a los terratenientes feudales que provenian de la ciudad-estado y algunas veces ayudaban a los campesinos de la ciudad a defenderse de otros seflores contrarios que residian en otras ciudadesestado. La historia de los patriarcas estaría situada en este transfondo del anteproto-Israel. El pre-éxodo de Israel con su Dios (Elohim) habria consistido en grupos que trataron de unir partes de la población contrarias a la ciudad-estado. Sus enemigos habrian sido los cananeos, una clase social, una élite que controlaba la estructura feudal.

Una parte de los proto-israelitas habría sido subyugada por Egipto y bajo Moisés habria roto sus cadenas feudales egipcias, habría entrado en Palestina bajo la protección de su Dios Yahweh, quien habría estado detrás tanto para su liberación del feudalismo, de la estructura social de la ciudad-estado, como para la dedicación a valores e ideales que supusieran las reformas sociales de esta ciudad-estado. Este grupo (el de "Levf") habria conseguido afianzar al protoIsrael. Yahweh habria tomado algunos de los atributos de Elohim a quien distintivamente habrían sido antadidos rasgos yahwistas. Las estructuras sociales de una nueva confederación habrán constituido un proceso de retribalización más que una salida del tribalismo de pastores, de nómadas. Un rasgo distintivo de este Yahweh, que fue quien animó a la confederación, es su preocupación por la igualdad social.

Si este análisis de Gottwald es aceptado, entonces, la tradición de Yahweh como un Dios de la alianza, que prolege al pobre $y$ al indefenso, estarla siendo vista como enraizada en la pregunta por la liberación y el igualitarismo que caracterizaron los desarrollos antiguos en el crecimiento de Israel.

En tiempos más tardíos se vuelve claro que los pobres son quienes sufren injusticia Son pobres porque otros han violado la ley de Dios. Se dirigen, por eso, desprotegidos y humillados, en oración a Dios. Se da un desarrollo más tardio cuando el término "pobre" toma un significado religioso. Este se vuelve sinonimo de piadoso y devoto en pasajes proféticos y en los Salmos. El pobre y el afligido encuentran gozo al escuchar las buenas nuevas de Dios (Is 29, 19; 61, 1). Los términos pobre y necesitado son aplicados al Israel exiliado y a Sión (Is 
49, 13; 51, 21). En los Salmos, los "pobres" son sinonimo de quienes buscan a Dios (Sal 69, 32). La pobreza se convierte en una palabra con connotaciones espirituales.

\section{La justicin y el pobre en los Salmos ${ }^{29}$}

Una primera etapa en el identificar al pobre de los Salmos consiste en examinar la conexión entre justicia y el pobre. Justicia-rectitud (mišpaù/sedägäh) son frecuentemente usados como sinónimos en los Salmos ${ }^{30}$. Las dos raices verbales (Ypt y sdq) son también equiparadas conjuntamente. Mišpat encierra ciertas conexiones legales. Mientras que el verbo ( $\$ p t)$ tiene un significado claramente jurfdico, éste no es el veredicto del juicio como si fuera lo más importante, sino más bien la eliminación de una injuria en que había consistido la violeción de la justicia. Por eso, ésta es una palabra adecuada para expresar la idea de salvar de la injusticia al pobre y al necesitado.

La idea biblica de justicia significa ser fiel a las exigencias de una relación ${ }^{31}$. Esto es verdad cuando se habla de Dios en el Antiguo Testamento, incluyendo los Salmos. Esto no está en contraste con otras cualidades del Dios de la alianza, tal como amor constante (hesed), misericordia (rahamim) o fidelidad ('emûnäh), pero, en algunos texlos, es virtualmente igual a ellas (Sal 36, 5-6). La justicia no es uno de los modos de ser de Dios, sino que los afecta a todos ellos. Expresa que Dios está en una relación correcta o justa, especialmente hacia el pobre y el desposeldo (Sal 146, 6-9). La persona justa esta en relación correcta hacia Dios, hacia los otros y hacia su tierra (Sal 112).

La justicia de Dios es una justicia salvffica en cuanto que Dios restaura la armonfa en el mundo, interviene en defensa del pueblo, perdona sus pecados y los libera de las cadenas. Esta justicia tiene también un elemento de juicio restaura al oprimido y condena al malvado. La justicia es poder salvador de Dios, fidelidad de Dios en el papel de Sefior de la alianza La justicia, también, representa una victoria sobre los poderes del mal, que pretenden la destrucción de la sociedad. Este poder salvífico de Dios está particularmente activo en relación a quienes están al margen de la sociedad:

El Seffor obra venganza y justicia

en favor de todos los que son oprimidos.

(Sal 103, 6; cfr. Sal 140, 13; 146, 7)

La justicia de Dios recibe especial énfasis en el entomo de los Salmos (Sal 47; 93; 95-100). Algunos Salmos hablan del pobre en relación a las justicias divina e interhumana. Por ejemplo, los Salmos 111 y 112, compuestos probablemente por un mismo autor después del exilio, tienen la justicia divina y la justicia interhumana como tema común. La persona justa distribuye generosamente al pobre y la justicia de tal persona durará por siempre. El justo "dirige los asuntos con justicia" y sera premiado con riquezas. La doble declaración acerca 
de la justicia que dura por siempre en el contexto de poseer y de distribuir riquezas, incluye la noción bíblica de que los bienes de esta tierra son el signo de la relación correcla con Dios en la medida en que ellos son usados para crear amonía dentro de la comunidad.

La justicia de Dios es la reclitud de Dios, particularmente hacia los que han sido marginados de la sociedad:

Dios, por siempre fiel, da justicia a quienes se les niega,

da pan al que está hambriento, da libertad a los presos.

Dios abre los ojos de los ciegos,

Dios endereza a los que andan encorvados,

Dios protege al forastero, se cuida del huérfano y de la viuda.

(Sal 146, 6-9)

De acuerdo, a los Salmos 9-10, Dios es un juez de justicia, vence al injusto, oye el clamor del pobre y es una plaza fuerte para el oprimido. El hecho de que la justicia de Dios esté activa hacia el pobre y el oprimido indica que pobreza y opresión son un mal cuya liberación es buscada. El Salmo 72 expresa la esperanza de que el rey "juzgara" a los pobres con justicia, esto es, que él traerá justicia para ellos. El está para ejecutar la justicia de Dios. Es ministro de la justicia de Dios. Este Salmo habla de que la justicia de Dios afecta al mundo entero. La armonía en la sociedad y la paz vienen con la justicia La justicia bíblica, como es descrita aqui, es un requisito humano con carácter de atadura religiosa. Detrás del gobiemo del jefe terrenal está la justicia de Dios. La justicia del rey es una función y una imagen muy clara de la justicia de Dios prometida al pueblo, al pobre, según la cual no se permite que el débil se convierta en la presa del poderoso (vv. 1-2). Asimismo, la tierra trae abundancia porque la nación con su gobernante hace justicia (es decir, fidelidad a Dios, al projimo y a la tierra). El Salmo en su conjunto muestra (vv. 3.7.16) que el comportamiento humano y la naturaleza forman una unidad en la mentalidad de los israelitas. El trabajo del rey en favor de la justicia para el pobre (vv. 12-17) significa que él es una fuerte ayuda para quienes no tienen normalmente ayudas y defensas; estín indefensos. Los pobres son considerados consanguíneos del rey; él está obligado a rescatarlos prescindiendo de cualquier lazo afectivo (v. 14). En este salmo se ve claramente que los material y socialmente pobres son la preocupación de la justicia real.

El Salmo 76 indica que la justicia de Dios se acerca al oprimido a través del mundo entero. El criterio para distinguir a Yahweh de los otros dioses es la capacidad de lograr justicia para el débil, el huérfano, el alligido y el necesitado. y de protegerlos de la injusticia del poderoso (Sal 82). Esta preocupación por el 
indefenso en la sociedad, no es simplemente un mandamiento dado para promover la armonía social, sino que está enraizada en la naturaleza de Dios que es el defensor del oprimido.

\section{¿Quiénes son los pobres en los Salmos?}

Algunos escritores subrayan el aspecto religioso de la pobreza en los Salmos, diciendo, por ejemplo, que los Salmos acerca del pobre vienen de un grupo definido, los 'anöwîm, quienes consitufan una clase o comunidad, y no una aclitud de esplritu32. "Pobre", por tanto, se refiere a los miembros de un grupo religioso o "asociación piadosa", particularmente cuando aquéllos se ponen en contraste con el "malvado".

Otros reaccionan fuertemente en contra de una sobreespiritualización de los Salmos. J. P. Miranda busca entender al pobre en muchos Salmos en referencia a la injusticia, a la pobreza material y social y a la opresion ${ }^{33}$. H. J. Kraus advierte que no deberamos sacar conclusiones tan rápido sobre una designación religiosa y espiritual de los pobres. En primer lugar, es un asunto de cualquier forma de pobreza, indigencia y amenaza hostil, que encuentra su expresion en el trmino "pobre". Los pobres, dice, son gente cuya necesidad los hace esperar todo de Dios y su actitud interna corresponde a estow. W. E. Pilgrim también busca mantener un balance entre el aspecto religioso y material de la pobreza en los Salmos: "Aunque es verdad que encontramos una espiritualización del concepto de pobre en el Salterio, eso no es todo. Las situaciones vitales política y social se siguen manteniendo. Las situaciones de desgracia son las de pobreza literal, persecución, opresión, aflicción y otras parecidas. Los pobres son realmente las victimas de la vida y sus enemigos son los poderosos y los "adinerados". El afirma que "el único rasgo más sobresaliente acerca del pobre en los Salmos" es "la identificación entre el socialmente pobre y el religiosamente piadosoms.

Pero, ¿cuál es la naturaleza de esta identificación? Ante todo, ciertos pasajes en los Salmos prestan más atención a las actitudes internas del "pobre" en relación con Dios. Está establecido que ellos claman a Dios, están atentos a la voluntad de Dios. Muestran un espiritu de confianza en y de dependencia de Dios. Estin junto a los "rectos-justos" y a los que "buscan" a Dios. Se da un contraste entre la actitud hacia el "malvado" y la actitud hacia el pobre, el justo y el fiel ("piadoso"). Por ejemplo, el Salmo 25 subraya las actitudes internas del pobre en relación con Dios:

Mírane y ten lástima de mi, porque soy pobre desvalido ('änt).

(v. 16)

Esta cación individual de petición expresa algunas actiudes internas. El "pobre" es llevado por Dios a hacer lo que es reclo, se vuelve a Dios en aclitud 
de dependencia, "teme" a Dios (es decir, responde con reverencia y atracción hacia la palabra y la gracia de Dios) y "espera" en Dios, en el sentido de estar de acuerdo con la voluntad de Dios en un espíritu de confianza y expectación. Esta persona "pobre" ambién experimenta la necesidad de perdón. Generalmente en aquellos Salmos donde el autor habla de sí mismo como "pobre" en primera persona, estas actitudes internas de pobreza ante Dios aparecen más claramente, sobre todo en los Salmos 69 y $109^{36}$. Y sin embargo, algunas veces, el aspecto material y social de la pobreza no se excluyen mutuanente. Por ejemplo, el "pobre y necesitado" del Salmo 109 expresa un fuerte espíritu de conflanza en y de dependencia de Dios. Pero un significado exclusivamente religioso no es el que se supone en la condena de la persona "malvada" que:

...persiguio al pobre, al necesitado

y al desanimado hasta su muerte.

(v. 16)

Algunos Salmos indican claramente que el significado predominante de "pobre" es quien pone su dependencia total de Dios, quien suplica abandonado ante Dios, como la persona afligida, pobre ('änî), del Salmo 88 (v. 15). También el religiosamente pobre de los Salmos podría simplemente ser quien estú claramente necesitando del auxilio de Dios para que le oiga y le rescate, aunque su actitud interna hacia Dios no esté descrita (Sal 12, 5; 14, 5). Algunas veces es dificil saber si "pobre" se refiere a una actitud de dependencia hacia Dios o a una situación de despojo o injusticia. En tales casos, ambos sentidos podrían ser incluidos. Por ejemplo, el Salmo 149 (v. 4: 'anōwîm), que celebra una victoria, podría referirse al pobre y desposeído al que Dios cuida o a la gente de Israel en su conjunto. Cuando los desvalidos ponen su confianza en Dios, son liberados no por su propio poder, sino por el poder de Dios. En este sentido, ellos serlan espiritualmente pobres.

En segundo lugar, el aspecto económico y social de la pobreza está muy claro en aquellos Salmos, que se refieren a los pobres en contextos en que el aspecto espiritual de la pobreza no es mencionado ni implícita ni explícitamente. Esta tendencia aparece en alguno de estos Salmos que vinculan justicia con el pobre. Además, la mención, algunas veces junto a los pobres, de viudas, de mujeres estériles, de huérfanos y emigrantes, demuestra que el énfasis está puesto en gente que es social y materialmente pobre:

Padre de los huérfanos y protector de viudas es Dios...

Al solitario, le da hogar, al preso, le quita sus cadenas; a los rebeldes, los deja en calabozos.

En tu bondad, Dios, tu provees a quien está necesitado.

(Sal 68, 5-6. 11) 
Desde el polvo levania al miserable, de la mugre retira al desvalido para darle un asiento entre los nobles... El da a la mujer estéril una familia...

(Sal 113, 7-9)

Por consiguiente, los pobres son quienes han sido reducidos a la pobreza o a la miseria a causa de varias desgracias de la vida También los pobres son simplemente aquellos malerialmente necesitados a los que las personas "justas" distribuyen riquezas gratuitamente ( $\mathrm{Sal} 112,9)$.

Con respecto a las mujeres en los Salmos, viudas y mujeres que no pueden engendrar, deben ser incluidas entre los pobres de Israel ${ }^{37}$ y se les describe en este contexto. En el sistema de farnilia patriarcal de Israel, la situación de una viuda sin hijos podía ser desesperante; se la dejaba frecuentemente sin ninguna ayuda o derechos de propiedad después de la muerte de su marido. La muerte antes de la vejez era normalmente considerada como un castigo por el pecado que se extendía a la esposa que quedaba viuda. Las viudas no tenían ni voz ni voto en Israel, - la palabra hebrea 'almänöh que tiene un parecido con 'älam ("ser callado". "ser mudo") sugiere la mudez a la que es forzada por la desgracia de la viudez. No hay que sorprenderse de que Isalas hable de los "desprecios que te hacian cuando viuda" (Is 54,4).

La mujer estéril compartia con la mujer que habla perdido sus hijos el mismo futuro precario. Además, ella sufria una inmediata privación social y psicológica por su incapacidad de proctear. La incapacidad de tener hijos era algo despreciable. Era interpretada como un castigo divino o al menos como una seMal del descontento divino. Esto trafa como consecuencia una burla de parte de las otras mujeres, especialmente de las concubinas quienes podfan procrear, y esto amenazaba al estatus de la mujer como esposa. La mujer incapaz de procrear era privada de honores adheridos a la maternidad; - la única posición de honor generalmente accesible a las mujeres, era la de la maternidad, la cual representaba el estatus más alto que podía ser alcanzado por ellas. Los huérfanos eran frencuentemente asociados a viudas y emigrantes - personas cuyas vidas eran caracterizadas por su dependencia humillante- en las súplicas biblicas de que se tenga compasión para con quienes están al margen de la saciedad (cfr. Sal 146).

El pobre también es descrito como aquél que está hambriento de pan, a quien Dios provee de provisiones (Sal 132,$15 ; 146,7$ ). Hay suficientes ejemplos para ilustrar que el pobre a veces es simplemente aquél que está desposeldo material y socialmente, y que sufre injusticia y opresión. No hay espiritualización del pobre en estos textos.

En tercer lugar, algunos Salmos describen personas que son social y mate- 
rialmente pobres, oprimidas, y al mismo tiempo religiosamente pobres. El Salmo 14, es una oración comunitaria de petición, describe la opresión del pobre, que implica injusticia, en términos similares a los de los profetas (Miq 3). Oprimir al pobre es una forma práctica de ateísmo en un mundo sin Dios. Es la obra de un "insensato" ( $c f r$. vv. 1.4.6). Al mismo tiempo, Dios es el refugio del pobre. Dios escucha su clamor. Los Salmos 9 y 10 mencionan frecuentemente al pobre en el contexto de un lucha mundial por la justicia en la que Dios apoya al oprimido y al pobre (Sal 9, 7-9). El cuidado de Dios para con el pobre no depende de la raza o la nacionalidad, ni de si la victima de la injusticia cree en Yahweh o no. La justicia y la equidad de Dios tienen un alcance universal. Los pobres son alineados con el oprimido (dak, 9, 9), el miserable y el huérfano (10, 14-18). Ellos son fieramente perseguidos y oprimidos por gente malvada, que abusa de su poder y que es avara de ganancias. Los pobres son descritos como los equivocados y los no privilegiados de la sociedad, de suerte que la pobreza económica y social está implícita. Al mismo tiempo, ellos son espiritualmente pobres, ellos gritan a Dios por su liberación y su esperanza (Sal 9, 12.18; 10, 14.17). Por otro lado, el opresor injusto del pobre no cree en la justicia de Dios $(10,3-9)$.

La pobreza o allicción de una persona inválida e impedida se describe vivamente en el Salmo 88 ('onî, v. 9). Esta oración es un profundo y conmovedor testimonio de la dificulad que quienes creen en Dios pueden experimentar cuando sienten que Dios está callado, que sus oraciones no son escuchadas y cuando ellos se sienten estigmatizados ante la sociedad y sus amigos. La confianza combativa y llena de coraje ante Dios por parte del pobre y del incapacitado, es muy real. El Salmo 102 es titulado "la oración de un pobre", un afligido ('äni), que sufre soledad, dolor y está críticamente enfermo. El orante, sin embargo, está dominado por un espiritu de esperanza y confianza en Dios.

Finalmente, aun en el caso de los Salmos que expresan o enfatizan el aspecto espiritual de pobreza, la experiencia de ser espiritualmente pobres esta relacionada con situaciones concretas muy humanas. Fuera de estas situaciones, el pueblo experimenta que necesita la ayuda de Dios. La experiencia espiritual de pobreza es inseparable de las siluaciones personales de pobreza, tales como el odio, la persecución por enemigos inciertos con el resultado de soledad, asf como el sentido de culpa por los pecados cometidos (Sal 25), las agresiones humanas, el alejamiento de la familia (Sal 69), la calumnia, el abandono por parte de los amigos (Sal 104), las amenazas de muerte, los rechazos por parte de los "malvados" y quizá los sufrimientos físicos (Sal 34), la enfermedad, la prisión, la soledad (Sal 22), la persecución por gente arrogante y cruel (Sal 80), y la incapacidad (Sal 88).

Ciertamente, la desgracia del "pobre" en los Salmos se refiere a veces a las 
penalidades económicas y políticas con su consecuente opresión y sufrimiento. Pero el círculo es aún más amplio que estas enfermedades sociales, ya que la experiencia de ser pobre es también una enfermedad así como diferentes clases de conflictos religiosos y morales como, por ejemplo, la soledad, el aislamiento y la persecución. Pero en todas estas situaciones, excepto cuando la gente se experimenta a si misma como pobre por sus pecados, cuando la culpa es responsabilidad de uno mismo, el pobre se ve a sf mismo esencialmente como víctima, que suplica a Dios ayuda y venganza.

\section{Los opresores del pobre}

Generalmente, los pobres no son contrastados con los ricos, sino más bien con los "malvados" (rešä'îm) o con enemigos que colocan al pobre '(änî) en su posición más baja y lo mantienen allf. Los "malvados" practican violencia contra el pobre y el débil, explotan al huéfano y a la viuda y practican la injusticia y el engafio. Constantemente se oponen al pobre (Sal 37, 1.12; 82, 3-4; $109,2 ; 140,1.12 ; 146,9)$.

Los pobres son las víctimas de los malvados y buscan refugio de ellos en Dios. En el Salmo 82, Dios es invocado para defender al pobre y al necesitado en contra del malvado. Los "malvados" son descritos en términos de agresión hacia sus vecinos y también como enemigos de Dios (Sal 92, 7-8). De acuerdo al Salmo 37, los malvados son aquellos que sacan sus espadas y doblan sus arcos para daftar al pobre y al necesitado, mientras que el justo-recto da generosamente de su compasión (vv. 14. 21).

El justo y el pobre están íntimamente asociados. Ambos son puestos en contraste con el "malvado". El pobre y el jusw tienen mucho en común: ambos son acosados por el malvado y ambos están bajo la protección especial de Dios. Dios nunca olvida al pobre y al justo. También puede ser que el pobre sea visto cada vez más como justo y recto, precisamente, porque el opresor es tan injusto para con él.

\section{El pobre y el rico}

Los Salmos expresan varias actitudes hacia el rico. En el Salmo 49, el pobre y el rico son animados a escuchar juntos el mensaje del salmista acerca de las riquezas (v. 2). Aquí y en el Salmo 73 se plantea la pregunta por las desigualdades de la vida. La respuesta es que la riqueza y lodo recurso humano terminan. No pueden damos sabidurfa verdadera y una seguridad absoluta. No se discute que la riqueza sea mala en sf misma, sino que su importancia puede ser mal entendida. Dios no puede ser comprado y ninguna riqueza, por muy grande que sea, puede alterar los propósitos de Dios (Sal 49, 7). La riqueza no puede continuar en los ricos para siempre. En este Salmo ellos son poderosos e influyentes. El salmista toma una postura negativa frente a ellos. 
En el Salmo 73 no se menciona al pobre. Tampoco el rico es mencionado explfcitamente. Pero el autor describe a personas violentas, arrogantes y agresivas, con gran influencia, que crecen en riqueza y prosperidad. Hay una descripción larga y objetiva de estos opresores ricos e influyentes que imponen con éxito sus demandas a aquellos sobre los que muestran su poder conquistado por su riqueza. No es tanto la injusticia de los ricos opresores lo que causa el angustioso cuestionamiento de este salmo, cuanto su éxito completo al conseguir que el oprimido acepte esto como inevitable (vv. 8-12). Ellos parecen tomar el papel de Dios ${ }^{38}$.

Algunas veces, los Salmos representan una visión negativa de los ricos: ellos pueden alejar a la gente de la confianza en Dios (Sal 49, 6-8; 52, 9). La riqueza como una bendición levanta preguntas, ya que muchos "malvados" son gente rica y afortunada, mientras que muchos "justos-rectos" parecen ser desafortunados y pobres. Pero Dios establecerá un orden correcto de cosas. La riqueza terrenal y la fortuna son pasajeras. La fe en Dios es más grande que cualquier riqueza (Sal 37; 49; 73).

Por otro lado, como en las tempranas tradiciones del Antiguo Testamento, las riquezas pueden ser vistas como un regalo y una bendición de Dios. Los bienes de esta tierra son la seftal de la correcta relación con Dios, en la medida en que sean medio para crear armonia dentro de la sociedad. Además, los efectos de la justicia son que la tierra producirá abundancia futura, y es una bendición de Dios a la gente el hecho de que se socorra a quien ha sido despojado (Sal 72; 107; 132).

\section{El Dios de los pobres}

El Dios de los pobres está caracterizado sobre todo por tener la justicia a su cuidado. El pobre está confiado a la justicia de Dios, del rey y también de los mismos justos-reclos. No es que el amor (hesed) de Dios y la temura (rahamîn) estén separados, en contraste con las cualidades del Dios de la alianza Son virtualmente identificados en algunas ocasiones (Sal 36, 5-6). El Salmo 103 asocia la justicia de Dios, que reivindica al pobre y vence la opresión, con la compasión, la ternura y el amor, haciendo referencia a la revelación dada por Dios a Moists (Ex 34, 6-7): "El Sefior es misericordioso (rahlam) y lleno de gracia (hannan), lento para la ira y grande en ternura (hesed)" (Sal 103, 6-8). El "pobre y necesitado" del Salmo 86 da gracias por la compasión y misericordia de Dios, el amor y la gracia ( $c f r$. vv.3.4.13.15). La compasión de Dios está especificamente en que es solidaria con el necesitado. De nuevo, en los Salmos 111 y 112, que tratan sobre la justicia divina e interhumana, la compasion (rahem) de Dios eslá ligada con su justicia (Sal 111, 3-5; 112, 3-9) en relación con el desposeido y el necesitado. La justícis se relaciona con los "sentimientos de las entrafias" de Dios hacia el pobre. Compasión y perdón (rehem, rehamîn, ra- 
hhom), en su rafz denotan el amor de una madre por el hijo de sus entrafias y generan un conjunto de sentimientos, incluyendo el de la bondad y la ternura ${ }^{39}$. Esto sugiere un aspecto femenino de la justicia de Dios hacia el pobre.

El cuidado de Dios por el pobre, su justicia, está también vinculada a la alianza de amor (hesed). Algo esencial para la alianza fueron los diferentes mandamientos respecto a quienes estaban en necesidad de ayuda: los esclavos, los extranjeros, la viudas, los huéfanos, los pobres (Ex 22-23). En los Salmos, los pobres están confiados a este "amor de Dios". Hesed es una palabra hebrea que expresa una actitud profunda de bondad y fidelidad en virtud de un mandamiento. Además de este especial encargo de amor, Dios se preocupa por el hambriento y sediento, y libera a la gente de la opresión y rescala al afligido. La fuerza de su amor es enfatizada. Es la solidaridad de Dios con el pobre y contra sus opresores por la búsqueda de la justica. Es una actitud volitiva, orientada al concepto de derecho y vinculada fuentemente con el poder a través del cual Dios cambia las situaciones del pobre y del malvado:

El Seffor tiende la mano a los humildes, pero humilla hasta el polvo a los malvados...

Le agradan al Seffor los que le temen, los que esperan en su amor fiel.

(Sal 147, 6.11)

Amor (hesed) y compasión (rahûm) son la base sobre la que Dios muestra su fuerza de apoyo a los pobres. El amor activo de Dios hacia el pobre es visto como una lucha, como una guerra viva, en este salmo en el que Yahweh es el guerrero ${ }^{40}$, que "tiende la mano al necesitado y golpea al malvado contra el polvo" (v. 6; cfr. vv. 10-11). Este Dios guerrero, sin embargo, es molivado por compasión y amor (vv. 1. 11). El Salmo 74 también caracteriza a Dios como un héroe de batalla (vv. 12-14). La guerra es contra la opresión de suerte que el "oprimido no vuelva avergonzado" y que "el pobre y el necesitado puedan alabar tu nombre" (v. 21). En contraste con Yahweh, están los poderosos que son injustos. Ellos atemorizan y devoran a la gente. Esta es la guerra del héroe salvador (vv. 3-11).

\section{El grito del pobre}

En general, los Salmos son expresiones sinceras de lo que se siente. Son grito del corazón a Dios, expresando actitudes fundamentales hacia Dios y la vida humana. El grito del pobre es una llamada para Dios ( $q \dot{a} a)^{41}$ y también un grito de profunda aflicción $\left(s \bar{a}^{\prime} a q\right)^{42}$. El pobre y el necesilado imploran a Dios para que los oiga y les conteste en su anguslia y su petición está llena de confianza ${ }^{43}$. El grito del pobre en los Salmos 9 y 10 es el de una persona cuya fe en Dios es puesta a prueba por la opresión, que tiene que luchar por la preservación de esta confianza, que se pregunta si Dios se ha olvidado o por que Dios 
esta silencioso. Ahora bien, Dios nunca está tan ausente para los pobres, como perra no poder estar presente a la hora de su grito, de suerte que ellos pueden expresar su fe en que siempre hay esperanza para el pobre. Además, las tradiciones de fe en Israel de que Dios siempre ha ayudado al pobre y oprimido son base de esperanza. El pobre y el justo a veces cuestionan la justicia de Dios porque sus opresores no sólo prosperan, sino que también los atacan, condenan y se burlan de ellos, porque creen que Dios vendra a rescatarlos.

Pero ellos saben que Dios se levanta en su favor, "piensa en ellos", oye su grito, sus deseos. Y no sólo Dios, sino que también el rey oye el grito del pobre. Esto es lo que se espera del gobernante del pueblo:

Porque él (el rey) libera al necesilado que llama, al pobre y a aquél que no tiene quien le ayude.

$($ Sal 72,12$)$

\section{Imágenes para el pobre}

Algunas imágenes de los Salmos transmiten vivencialmente to humano, o mejor dicho, las experiencias deshumanizadoras de ser pobre. La soledad, la persecución, el abandono y el sentimiento de ser extranjero para la sociedad, que son experimentados por el pobre, son algunas veces mencionados ${ }^{\mu}$. Experiencias como estas son comunicadas en forma de inágenes's. Por ejemplo, se establece que Dios

...levanta al pobre del polvo,

y retira de la mugre al necesitado, para hacerle sentar entre los nobles.

(Sal 113, 7-8)

Esta vivencia comunica el contraste entre el pobre y el poderoso. La imagen es la de los basureros en las afueras de la ciudad o villa, que se habian convertido en el refugio del pobre, los marginados y enfermos. Ahi, mendigan para encontrar algún mendrugo de pan y para dormir.

La fuerza y la crueldad del opresor son como un león esperando a su presa o como un cazador, que agarra animales en una trampa; pero Dios es el libertador que saca al afligido, al pobre, fuera de la trampa, o los libera de los lazos de la opresión. La agresión y violencia del malvado hacia el pobre es descrita en términos de armas de guerra, arcos, que, con la ayuda de Dios, se vuelven en contra del opresor. Dios es el héroe guerrero que rescata al pobre. El inútil, el pobre, se siente abandonado por sus amigos, "encerrado", aislado sin Dios. Dios "levanta", protege, al necesitado de su continua aflicción, poniéndole por encima de todo. Los pobres son "robados", "despojados", "saqueados". Ellos suspiran, gimen, bajo la opresión del malvado que los amenaza desde todas partes como animal ansioso de presa. Muchas de estas imágenes de los Salmos están 
tomadas de aspectos de la vida que son concretos para las personas que los rezan: a partir de la guerra y de la naturaleza. Escritores modemos han traducido algunas de éstas a imágenes contemporáneas de pobreza y opresión ${ }^{46}$.

En conclusión, aunque las imágenes pueden haber cambiado, muchas de las realidades de los Salmos permanecen actuales. Aunque no hablan del poder del pobre para ayudarse el uno al otro, y para ayudar a la transformación de la sociedad, ofrecen muchas visiones que dan fuerza al pobre y oprimido de hoy y a los que trabajan en su favor. Se hacen eco de la allicción del pobre a nuestro alrededor. Nos recuerdan que nuestro Dios es el Dios de los pobres, que el núcleo de la justicia divina e interhumana es la compasión y que todos somos llamados a ser espiritualmente pobres, a confiar en el fuerte amor de Dios que quiere que los bienes de nuestra tierra sean compartidos por todos.

\section{Notas}

1. C. Boerma, Rich Man, Poor Man - and the Bible (trad. J. Bowden), London 1979, 44.

2. Por ejemplo, E. Cardenal, Psalms of Struggle and Liberation (trad. E. G. McAnany), New York 1971; E. Cardenal Psalms (trad. T. Blackbum y otros), London 1981 ; D. Berrigan, Uncommon Prayer: A Book of Psalms. New York 1978.

3. Por ejemplo, G. Gutiérrez, A Theology of Liberation (trad. C. Inda, J. Eagleson), New York 1973, 288. 296-297.

4. En el presente artículo, que es traducción de un original inglés, se ha seguido, con pequeñas modificaciones, la traducción y la numeración de los Salmos de la llamada "Biblis Launosmericana".

5. Psalms (Old Testament Message), Wilmington, Delaware 1983, Vol. 1, 17-18.

6. Salmos 9; $10 ; 12 ; 14 ; 18 ; 22 ; 25 ; 31 ; 34 ; 35 ; 37 ; 40 ; 41 ; 44 ; 49 ; 68 ; 69 ; 70 ; 72 ; 74$; 76; 82; 86; 88; 107; 109;112;113; 119; 132; 140; 147; 149. Como adiciớn, 'àn aparece en el título del Salmo 102.

7. Por ejemplo, Sal 146.

8. En singular en los $S a l 10,2.9$ (dos veces); 14,$6 ; 18,27 ; 25,16 ; 34,6 ; 35,10$ (dos veces); 37,$14 ; 40,17 ; 68,11 ; 69,29 ; 70,5 ; 74,21 ; 82,3 ; 86,1 ; 88,15 ; 102,1$ (en el túblo del salmo); 109, 16. 22; 140, 12. En plural ('aniyyín) en los Sal 9, 12; 12 , 5; $72,2.4 ; 74,19$.

9. Sal 9,$18 ; 10,17 ; 22,26 ; 25,9 ; 34,2 ; 37,11 ; 69,32 ; 76,9 ; 147,6 ; 149,4$.

10. Cfr. L. Sabourin, The Psalms: their Origin and Meaning, New York 1969, Vol. 1, 99.

11. Sal 9,$13 ; 25,18 ; 31,7 ; 88,9 ; 107,10.41 ; 119,50.92 .153$.

12. Sal 22, 24.

13. Sal 9,$18 ; 12,5 ; 35,10 ; 37,14 ; 40,17 ; 49,2 ; 69,33 ; 70,5 ; 74,21 ; 109,16.22 .31$; 112,$9 ; 113.7 ; 132,15 ; 140,12$. 'ebyôn está estrechamente unido con'an̂î en Sal 35 , $10 ; 37,14 ; 40,17 ; 70,5 ; 74,21 ; 109,16.22$ y con dal en Sal 72, 13; 82, 3-4.

14. Sal 41,$1 ; 72,12.13 ; 82,3-4 ; 113,7$.

15. Sal 9,$9 ; 10,18 ; 74,21$.

16. Sal 10,8.10.14. 
17. Por ejemplo, Sal 146, 7.

18. Sel 82, 3 (con referencia a seres humanos); 34, 10 (con referencia a animales, por ejemplo, cachorros de león).

19. H. J. Kraus, Psalmen I (BKAT 15), Neukirchen-Vluyn, 5/1978, 82-83; A. A. Anderson, The Book of Psalms (New Century Bible), London 1972, Vol I, 269-270. 279-280.

20. Sal $18 ; 68 ; 76 ; 132$.

21. Sal 9; $10 ; 12 ; 31 ; 35 ; 44 ; 72 ; 109$.

22. Sal $22 ; 40 ; 74 ; 82 ; 149$.

23. Sal $14 ; 25 ; 34 ; 37 ; 41 ; 49 ; 69 ; 86 ; 88 ; 107 ; 112 ; 113 ; 119 ; 140 ; 147$.

24. Cfr. Anderson, The Book of Psalms, 119.

25. Cfr. Sal 31-32.

26. Cfr. C. Stuhlmuller, Psalms, Vol 2, $41-43$.

27. Rich Man, Poor Man, 7-20.

28. The Tribes of Yahweh, New York 1979.

29. Cfr. J. R. Donahue,'Biblical Perspectives on Justice", en The Faish that Does Justice, J. C. Haughey (ed.), New York 1977, 68-112, esp. 68-78; L. J. Topel, The Way to Peace, Dublin 1980, 71-76.

30. V. Hemtrich, "krino", TWNT, 3, 927.

31. J. R. Donahue, Biblical Perspectives, 68-69.

32. Pera una descripción de este punto de vista y una crítica válida del mismo, cfr. H. J. Kraus, Theologie der Psalmen, Neukirchen-Vluyn 1979, $188-193$.

33. Marx and the Bible, London 1977, 101-102.

34. Theologie der Psalmen, 190.

35. Good News to the Poor, Minnesola 1981, 30-31.

36. Cfr. también Sal 40, 16-17; 70, 5; 86, 1-7.

37. Cfr. P. Bird, "Images of Women in the Old Testament", en Religion and Sexism, R. Ruether (ed.), Dublin 1980, 41-88, esp. 53, 54, 62

38. Cfr. R. Haughton, "Christian Theology of Human Rights", en Underssanding Human Righis, A. Falconer (ed.), Dublin 1980, 224-236, esp. 225-226.

39. Cfr. P. Trible, God and the Rhetoric of Sexualiry. Philadelphia 1978, 31-56; Juan Pablo II, Dives in Misericordia (trad. London 1980), 21-22.

40. G. von Rad, Der heilige Krieg in Alten Israel, Gouingen 1951, 82.

41. Cfr. Sal 34, 6.

42. Cfr. Sal 9, 12.

43. Cfr. Sal 31,$8 ; 34,7 ; 40,18 ; 69,34 ; 86,1 ; 109,31 ; 140,13$.

44. Cfr. Sal 25; $41 ; 69$.

45. Cfr. Sal 10, 7-10; $12,5.8 ; 25,15-16 ; 69,33 ; 74,21 ; 88,8 ; 107,41$.

46. Cfr. nota n. 2. 